\title{
ENVIRONMENTAL POLICY FORMATION AND THE TAX TREATMENT OF CITIZEN INTEREST GROUPS
}

\author{
Charles J. Goetz* \\ Gordon BradY $\dagger$
}

\section{INTRODUCTION}

The development of environmental regulatory policy in the United States during recent years has been marked by the widespread participation and influence of what we shall term "CIGs" as an acronymn for "Citizen Interest Groups." The activities of such groups have frequently benefited from significant forms of public financial subvention, particularly through preferential tax treatment. Part I of this paper surveys the benefits of preferential tax legislation as they apply to the environmentalist CIG. Part II assesses the restrictions prerequisite to such preferential treatment. Finally, part III provides a brief commentary on the appropriateness of the legal treatment from the viewpoint of political economy.

Our results suggest that, although the preferential treatment available to environmentalist CIGs is of substantial value, the political restrictions attached to such treatment have probably not "cost" the CIGs any substantial reduction in their impact on policy. We do, however, find cause to entertain reservations about certain aspects of the current tax treatment of the environmentalist groups.

* Professor of Law, University of Virginia.

$\dagger$ Rockefeller Foundation Fellow in Environmental Affairs, Center for Studies in Law and Economics, University of Miami.

At the time this article was written, both authors were affiliated with Virginia Polytechnic Institute and State University, Goetz as Professor of Economics and Brady as a Ph.D. candidate in economics.

The authors wish to acknowledge the financial assistance stemming from a Ford Foundation grant to Professor Paul Downing, Virginia Polytechnic Institute and State University.

1. We use the term to refer to broadly based groups whose members share an interest other than narrow economic benefit. We assume that such groups qualify as "public" under $\S 509(a)$ of the Internal Revenue Code as amended by the Tax Reform Act of 1969. Many such entities are popularly known as "public interest" groups or law firms. For reasons which will become apparent in part 111 infra, we prefer to avoid the "public interest" terminology. 


\section{Environmentalist Benefits Under Tax-Exempt Status}

Environmentalist CIGs who successfully qualify under section 501(c)(3) of the Internal Revenue Code $^{2}$ enjoy certain valuable forms of public subsidy, applicable both to the cost and revenue flows of the organization. Qualification under this section of the statute renders the organization "tax exempt" with consequent benefits involving (1) direct avoidance of federal income taxes, ${ }^{3}$ and (2) an option to avoid "payroll" taxes levied in the form of social security and unemployment insurance contributions. ${ }^{4}$ In the practical sense, the income tax exemption is of relatively minor economic importance, since the typical environmentalist CIG tends to incur expenditures roughly equal to its receipts. By contrast, the exemption from social security and unemployment taxes has surprisingly high potential to reduce the effective price of labor services to an environmentalist group.

Although the exact magnitude of the potential labor subsidy attributable to payroll tax avoidance depends upon the relevant degree of "shifting" of such taxes between employer and employees, an exemption-related reduction of over 11 per cent on employee expenses would seemingly be possible. ${ }^{5}$ In practice, this potential subvention is exploited to a surprisingly low degree. For instance, most of the largest CIGs examined in our study have not chosen to opt out of social security coverage. This choice is not an absolutely indefensible one on strictly economic grounds. However, we argue that the benefits of opting out are normally clear-cut for any employee who has otherwise qualified for minimum social security program coverage. Sizeable recent and projected increases in both the tax rate and minimum annual contribution will, of course, tend to increase the future advantages of opting out and possibly also decrease whatever inadvertence currently exists with respect to the benefits of this option.

If the payroll tax exemption is elected, what effects can be expected? The labor subsidy should tend not only to increase personnel inputs, because their relative price is lowered, but also to benefit a particular CIG in rough proportion to the importance of wage payments in its budget. Based on our limited

2. INT. Rev. Code of 1954, as amended, Tax Reform Act of 1969, Pub. L. No. 91-172, 83 Stat. 487.

3. Treas. Reg. § $1.501(c)(3)(1967)$.

4. INT. Rev. Code of 1954, \&3121(b)(8)(B), \& 3306(c)(8), respectively.

5. In spring 1975, for instance, an employee social security (FICA) contribution was being levied on income up to $\$ 14,100$. Unemployment insurance taxes were being paid by the employer at a rate of 3.2 per cent on income up to $\$ 4,200$. The tendency of most economists is to regard all payroll taxes as borne economically by labor, regardless of the locus of the legal liability. J. Pechman \& B. Okner, Who Bears the Tax Burden? 25 \& n.1 (1974). This suggests that, ceteris paribus, a 501 (c)(3) organization could attract employees at lower nominal wage rates than non-501(c)(3) employers. For a nontechnical discussion of the alternative assumptions regarding the true incidence of payroll taxes, see $i d$. at 33,37 . 
sample of IRS information returns for well known environmentalist CIGs, it appears that the ratio of labor costs to total disbursements for exempt purposes varies widely, ranging from less than one-tenth to more than two-thirds, the modal percentage falling in the mid-thirties. ${ }^{6}$ Hence labor-cost subventions traceable to 501 (c)(3) status may have a potential magnitude of between three and four per cent of the budget of a typical environmentalist CIG with major national activities. Although possible confirming data are unavailable, we suspect that the smaller, local environmentalist CIGs benefit less from the labor subsidy because the labor services to such groups are predominantly voluntary. In any event, the potential importance of this de facto labor subsidy varies with an environmentalist group's particular view of its "mission" and the labor-intensity of those activities which are most contributory to that mission. For instance, a group emphasizing litigation or research would plausibly face a higher ratio of labor costs to total costs than a literature-oriented group which, by contrast, would face relatively high ratios of printing and mailing costs.

Section 501(c)(3) status also indirectly confers another substantial factorcost reduction, albeit one widely ignored in the literature on this subject. Under present Postal Service regulations, such status is a condition for obtaining a "Special Third Class" bulk mailing permit which, at this writing, permits mass mailings of printed literature at approximately one-third the postal rates charged to other organizations. ${ }^{7}$ Particularly to the larger, non-local CIGs, who wish to disseminate informational pamphlets and fund solicitations over wide geographic areas, the favorable mailing rates confer noteworthy financial advantages. Regional CIGs, who are tied to local issues and clientele, derive comparatively less potential benefit from the preferential mailing rates.

Besides reduction of cost items, qualification as a $501(\mathrm{c})(3)$ entity also creates very important revenue-raising advantages, since it allows the CIG to receive contributions which are deductible from the donor's taxes, particularly the personal income tax. ${ }^{8}$ The precise impact of the deductibility feature on the volume of charitable contributions has been subject to varying estimates. However, the best recent econometric studies suggest that the "price elasticity" of charitable giving to nonreligious entities is relatively high, a dollar's worth of tax-saving providing the stimulus for substantially more than a dollar's worth of incremental contributions. ${ }^{9}$ Price elasticity is essentially the ratio of

6. See note 13 infra.

7. For the determination of eligibility, see Postal Service Manual $\$ 134.5$ (1975). In spring 1975 , the special rate was $1.8 \notin$ per piece or $11 \notin$ per pound, whichever is greater. The regular bulk mail rate was $6.1 \not$ per piece or $32 \not \subset$ per pound, whichever is greater. Id. $\S 134.1$.

8. INT. Rev. Code of 1954, § 170(c)(2) (income tax); § 2055(a)(2) (estate tax); and § 2522(a)(2) (gift tax).

9. An estimate of the price elasticity of charitable contributions is given by Feldstein, Taxes and Charitable Contributions: Part II-The Impact on Religious, Educational, and Other Organizations, 28 
the percentage change in dollars contributed to the percentage change in the "price," or after-tax cost, of a dollar contributed. The price change impact of deductibility is equivalent to the fractional dollar of tax avoided on each dollar of otherwise taxable income. Consequently, the percentage change in volume of contributions can be approximated by the formula:

$$
\% \Delta Q=100 \epsilon[\mathrm{t} /(1-\mathrm{t})]
$$

where $Q$ denotes contributions, $\epsilon$ the price elasticity of contributions, $t$ the marginal rate on taxable income experienced by the CIG's potential contributors, and the square-bracketed term is the percentage change in the "price" of a dollar contributed. ${ }^{10}$

In addition to the magnitude of $\epsilon$, the formula listed above illustrates how the impact of deductibility on personal donations to environmentalist CIGs is critically dependent on t, the potential donor's tax bracket variable, and hence on income level. As we will discuss in further detail below, empirical evidence exists that the environmentalist clientele, as regards active members and contributors, is markedly upper-income in character. ${ }^{11}$ Therefore, even the assumption of extremely conservative values for $\epsilon$ and $t$, such as 1.0 and .25 respectively, would suggest that one-third or more of the personal contributions to environmentalist CIGs are contingent on 501(c)(3) status. ${ }^{12}$

In addition to personal contributions, the major sources of revenue for environmentalist groups are (1) grants from governments or other nonprofit foundations, and (2) revenue from sale of literature, research, etc. The ratio of personal contributions to total revenues varies widely but is frequently large, especially where the CIG is a "membership organization" such as the Environmental Defense Fund or the Wilderness Society. For instance, these two major organizations, both of which have exercised noteworthy influence on the environmental policy formation process, can apparently expect to de-

NAT'L TAX J. 209 (1975). The lowest estimate for any nonreligious charitable contribution is 1.19. Id. at 217. For other works by Feldstein dealing with estimates of price elasticity, see $\mathbf{M}$. Feldstein, Estate Taxation and Charitable Bequests 1974 (unpublished manuscript on file with the authors); M. Feldstein \& C. Clotfelter, Tax Incentives and Charitable Contributions in The United States: A Microfconomic ANalysis (Harvard Institute of Economic Research Discussion Paper No. 381, Sept. 1974).

10. This result is derived from a rearrangement of the price elasticity formula $\epsilon=\% \Delta \mathrm{Q} / \% \Delta \mathrm{P}$. Under existing deductibility provisions, the current "price" of donating is the rate of reduction (1 - $t$ ) in one's after-tax income. Repeal of deductibility would raise the "price" to unity, an increase of $\mathrm{t}$. Hence $\% \Delta \mathrm{P}=100(\Delta \mathrm{P} / \mathrm{P})=100(\mathrm{t}(1-\mathrm{t}))$. Finally, this substitution and rearrangement of the original formula result in the formula in the text.

11. The best single source on the socioeconomic status of environmentalists is R. DunlaP, THE Sociofconomic Basis for the Environmental Movement: Old Data, New Data, and ImPlications for the Movement's Future (Washington State University Scientific Paper No. 4350,1974 ). But see also the dissertation of A. St. George, untitled 1975 (unpublished thesis at University of California-Davis Library); W. Devall, The Governing of a Voluntary Organization: Oligarchy and Democracy in the Sierra Club, 1970 (unpublished thesis in University of Oregon Library).

12. See note 9 supra with respect to actual empirical estimates. 
rive about 40 per cent of their budgets from "membership dues" alone, not including additional "donations" made by members or other individuals. ${ }^{13}$ Unlike most membership dues, the dues payable to environmentalist organizations typically appear to be eligible for deductibility under the standard that "the rights and privileges of membership are incidental to making the organization function according to its charitable purposes and the only return benefit thereby obtainable is the satisfaction of participating in furthering the charitable cause." ${ }^{14}$ Although the eligibility of such membership payments is frequently noted on CIG solicitation materials, we suspect that at least some members may nonetheless subjectively associate the "dues" appellation with its normal non-deductibility, thus weakening the effect of the subvention which is legally available. ${ }^{15}$

In addition to its effect on the flow of funds to the environmentalist groups in the aggregate, deductibility even more powerfully influences the competitive position of individual CIGs who are seeking to attract the donor's favor from possible alternative recipients within the environmentalist "industry." Where other considerations are reasonably balanced, e.g., there exists a "close substitute" organization, the deductibility condition can be expected to loom as a critical one. From this standpoint, we hypothesize that CIGs organized around localized issues benefit less from deductibility than the large nationally-based groups. In many cases, there will be no substitute or competitive organization whose focus is upon a particular set of local issues. Hence, the price elasticity of donations to those organizations would be expected to be relatively low. Although the aims of the major national groups are differentiated to some extent, many potential donors will probably perceive the "products" of several of these major CIGs as extremely close substitutes.

Deductibility is, of course, of no advantage to a potential donor which itself enjoys tax-exempt status. Hence, $501(\mathrm{c})(3)$ status is not per se a critical consideration for environmentalist CIGs in attempting to attract foundation support. A similar observation applies to governmental sources as notably exemplified by the "public information grants" which have been awarded to numerous CIGs by the Environmental Protection Agency under the provisions of the Clean Air Act of $1970 .{ }^{16}$ Hence, the deductibility flowing from

13. Estimates derived from examination of IRS information returns (form 990) for recent years. Treas. Reg. \$ 1.6033-1 (1971).

14. Rev. Rul. 432, 1968-2 Cum. Bull. 104.

15. Out of curiosity as to what advice might be given by the IRS's telephone taxpayer advisory service, the authors raised the deductibility question with two different IRS tax advisors. In each case, we were advised that such dues were not deductible, once with hesitation and once with great assurance.

16. Clean Air Act $\$ 103(\mathrm{a})(1), 42$ U.S.C. \$ 1856b(a)(1) (1970). "Public Information Grants" to five California CIGs were announced in 38 Fed. Reg. 31238 (1973). The League of Women Voters and Clean Air Constituency (a coalition of ten environmental organizations including the Sierra Club) were among those receiving grants. 
$50 \mathrm{l}$ (c)(3) status should tend, ceteris paribus, to diminish the relative reliance of environmentalist CIG's on governmental and foundation sources for financial support.

In sum, the economic value of 501 (c)(3) status depends to a notable extent on a particular environmentalist organization's goals. This is true because (1) part of the tax exemption benefit is a function of the CIG's mix of input factors, and (2) the impact of deductibility varies with the organization's clientele and potential sources of alternative financial support. To the extent that a CIG is interested in activities where bulk mailing and hired labor are effectively used, tax-exempt status becomes increasingly valuable. Similarly, the deductibility of contributions is most valuable when an organization's appeal is to potential supporters who are highly sensitive to the tax treatment of their monetary contributions. Hence, little advantage accrues to a small local CIG using almost exclusively voluntary labor services and receiving primarily non-monetary forms of support or contributions in kind. Nonetheless, there can be little doubt that the provisions cited above have materially increased the resources available to environmentalist CIGs who qualify. The value of this preferential treatment should be contrasted to the next most favorable preference level, that available under section 501(c)(4). ${ }^{17}$ Under the latter section of the Code, "social welfare" organizations are accorded only the corporate income tax exemption denoted above as having relatively modest financial value to the typical environmentalist CIG. The Sierra Club and Friends of the Earth, Inc. are the best known 501(c)(4) organizations active in the environmental field.

What is the "price" that an environmental group pays to achieve the rather substantial differential financial benefits of 501 (c)(3) rather than (c)(4)? In theory, the more preferential treatment requires a rather substantial circumscription of the environmental group's permitted behavior. We examine this circumscription, in theory and in its estimated actual impact, in the following sections of this paper.

II

\section{Restrictions Attendant to Preferential Treatment}

To qualify for 501 (c)(3) status, an environmentalist CIG must be organized and operated for one or more of the purposes regarded as falling within the intent of that section. Activities of environmental groups have apparently been deemed to fall under the categories of "charitable," "educational," or "scientific" as defined by the Internal Revenue Service. ${ }^{18}$ Qualification under the "charitable" rubric is presumably of some importance to an environmental interest organization, since the latter two categories, by requiring a more bal-

17. Treas. Reg. $\$ 1.501(c)(4)$ (1959).

18. Treas. Reg. $\$ 1.501(\mathrm{c})(3)-1(\mathrm{~d})(1967)$. 
anced presentation of information, may preclude some forms of "advocacy" exercisable through the media and various other channels. ${ }^{19}$ Environmental litigation, a particularly effective weapon of environmentalist CIGs in recent years, appears to fall explicitly within the IRS definition of charitable. For instance, the guidelines advanced for exempt activities of public interest law firms require "representation of a broad public interest rather than a private interest" and the example of "some specific area of public concern, such as protection of the environment" is explicitly noted. ${ }^{20}$

Additionally, a $501(\mathrm{c})(3)$ environmentalist organization must not devote a "substantial" part of its activities to influencing legislation "by propaganda or otherwise" in any of several ways: ${ }^{21}$

1) Legislative contact, in which the organization approaches, or urges the public to contact, any legislator:

2) advocacy of the adoption or rejection of a law or referendum; or

3) partisan advocacy of primary objectives which may be attained only through legislative action.

Further, such organizations are absolutely barred from intervention, directly or indirectly, in a political campaign on behalf of any candidate for public office.

These proscriptions, the first three of which delineate the Treasury's concept of an "action" organization, obviously impede a CIG from utilizing certain methods which might otherwise be extremely efficacious means to environmentalist ends. Hence, circumscription of political activity is the "price" a group pays for the considerable benefits described in part I above.

Qualification for the more modest privileges of 501(c)(4) status is open to the environmentalist CIG as a "social welfare" organization. ${ }^{22}$ A social welfare organization which could qualify under $501(\mathrm{c})(3)$, were it not for its political activities, is released by 501 (c)(4) from the prohibitions against "action" organization activities, but it is not released from the proscription of campaign intervention. ${ }^{23}$ In particular, a $501(\mathrm{c})(4)$ entity may, for example, lobby, take official stands on impending legislation, or urge its members to contact legislators.

Both the statutory language and the Treasury's administrative guidelines are the products of a long history of torturous evolution and reinterpreta-

19. See E. Berlin, A. Rotsman, \& G. Kessler, Law and Taxation 21, 22 (1970) in connection with the activities of "conservation" groups. The parallel with environmental groups is close, although the scope of an environmentalist CIG's activities is somewhat broader.

20. Rev. Proc. 39, $1971-2$ Cum. Bull. 575 (emphasis added).

21. Treas. Reg. § 1.501 (c)(3)-1(c)(3) (1967).

22. Social welfare organizations are required to be "primarily engaged in promoting in some way the common good and general welfare of the community." Treas. Reg. $\$ 1.501(c)(4)$ 1 (a)(2)(ii) (1959).

23. Treas. Reg. § $1.501(\mathrm{c})(4)-1(\mathrm{a})(2)(\mathrm{ii})$ (1959). 
tion. ${ }^{24}$ In spite of the recent attempt at clarification, ${ }^{25}$ it might be expected that any organization which contemplates activities falling within the "gray areas" of the political action guidelines should be motivated to adopt an extremely risk-adverse interpretation of permissible activity, avoiding controversial programs. If so, the environmentalist CIGs would be particularly susceptible to this influence since implementation of their objectives typically involves some instrumentality of the state, whether it be legislative, judicial, or administrative.

In examining the record of environmental CIGs during the past decade, the chilling effect of the political proscriptions attached to tax exemption benefits seems more potential than real. As we will elaborate below, three major mitigating factors appear to account for the comparatively minor effect of legal restraints on the policy impact of environmentalist CIGs: (1) interlocking $501(\mathrm{c})(4)$ and $501(\mathrm{c})(3)$ organizational forms which partially circumvent the operation of the law; (2) a relatively tolerant attitude on the part of IRS; and (3) political circumstances which, in our opinion, suggest that the high-return activities of the environmentalist entities have in any case been chiefly in areas which are perfectly permissible under $501(\mathrm{c})(3)$.

The major form of organizational circumvention involves "splitting" a CIG's activities into interlocking foundations, one of which observes the $501(c)(3)$ restrictions and receives tax deductible contributions. This 501 (c)(3) foundation is, in turn, operated for the benefit of a parent group which is an "action" organization engaging in legislative and advocacy activity within the meaning of $501(\mathrm{c})(4)$ and the pertinent IRS guidelines. This split is feasible provided that the parent group is "publicly supported" in the sense of relying on membership fees or other contributions from the general public. ${ }^{26}$ The two largest 501(c)(4) environmentalist CIGs, the Sierra Club and Friends of the Earth, exemplify this technique since they both utilize 501(c)(3) foundations as conduits for deductible contributions. ${ }^{27}$ F.O.E. carries the organization specialization a step further by carrying on a cooperative "sister organization" arrangement with the League of Conservation Voters, an en-

24. Early history of the federal tax exemptions is related in Reiling, Federal Taxation: What Is a Charitable Organization?, 44 A.B.A.J. 525 (1958). Historical developments relevant to charitable entities are outlined in Clark, The Limitation on Political Activities: A Discordant Note in the Law of Charities, 46 VA. L. REv. 439 (1960) and in Note, The Revenue Code and A Charity's Politics, 73 YALE L.J. 661 (1964). Finally, recent changes are reflected in Garrett, Federal Tax Limitations on Political Activities of Public Interest and Educational Organizations, 59 GEo. L.J. 561 (1971), and in Note, Political Activity and the Tax Exempt Organizations Before and After the Tax Reform Act of 1969, 38 Geo. WaSh. L. REv. 1114 (1970).

25. Rev. Proc. 75-13, 1975 Int. Rev. Bull. No. 10, at 46, which purports to "amplify Rev. Proc. 71-39, 1971-2 C.B. 575, by setting forth procedures under which a public interest law firm may accept fees for its services."

26. Treas. Reg. \& 1.509(a)-3 (1972).

27. The Sierra Club Foundation and Friends of the Earth Foundation, respectively. 
vironmentalist CIG whose direct political intervention activities disqualify it even from $501(\mathrm{c})(4)$ status. $^{28}$

A $501(\mathrm{c})(3)$ foundation may not control a $501(\mathrm{c})(4)$. However, nothing prevents a $501(\mathrm{c})(3)$ organization from contracting with any other organization for services which are consistent with deductible status. ${ }^{29}$ Likewise, several 501(c)(3) organizations could pool "insubstantial" contributions toward joint lobbyist or advocacy representation. The Washington-based lobbying activities of the Environmental Policy Center reflect, to some extent, financial support from a coalition of environmental groups. ${ }^{30}$

The option of using this organizational split-up technique provides a CIG with the ability to insulate its tax-preference activities from political "taint," while still reaping important deductibility benefits. Of course, deductible contributions must nominally be spent for purposes consistent with 501(c)(3) status. However, where control is truly interlocking, the essential fungibility of such funds is an economic reality; cross-subsidization occurs because "money mixes" from the decision-making standpoint even if not from the accounting one. ${ }^{31}$

While we recognize the overhanging threat, we find surprisingly little objective historical evidence to suggest that the IRS has attempted arbitrary or aggressive enforcement of the statutory guidelines in cases which substantially affect environmentalist CIGs. The major case of 501(c)(3) revocation in the environmental sphere involves the Sierra Club, whose tax deductibility privileges were revoked by the IRS on grounds that the Club came within the operational test which precludes "substantial" legislative activity. ${ }^{32}$ While we do not necessarily agree with the guidelines invoked by IRS, we are persuaded that the "political" activities attributed to the Sierra Club were in fact reasonably clear violations of the guidelines. ${ }^{33}$ Among the chief items were findings by the IRS that the Club (1) regularly formulated official positions on proposed legislation; (2) pursued these positions both by mail, magazine, and newspaper solicitations of its members and the general public as well as by employment of a professional Washington lobbyist; and (3) elevated the

28. L.C.V. "rates" members of Congress on environmental issues and campaigns for favorable candidates.

29. See E. Berlin, A. Roisman, \& G. Kessler, supra note 19, at 28.

30. Interview with Joseph Browder, Director of the Environmental Policy Center, by telephone, March 1, 1975. E.P.C. has, in turn, also started an ancillary 501 (c)(3) deductible foundation, the Environmental Policy Institute.

31. This fungibility problem is familiar in government finance when the grantor government attempts to restrict the use of the grants to certain purposes. Applications to state-local school subventions are analyzed in Bishop, Stimulative Versus Substitutive Effects of State School Aid in New England, 17 Nat'l TAx J. 133 (1964), and to federal-state revenue sharing in C. Goetz, What Is ReVenue Sharing? 11 (1972).

32. Letter Ruling, 6 P-H 1967 FED. TAXES 954,664 (Dec. 16, 1966).

33. This opinion seems to be shared in Note, The Sierra Club, Political Activity, and Tax Exempt Charitable Status, 55 GEo. L.J. 1128 (1967). 
legislative program to a "regular, formal, purposeful part" of the Club's operations. ${ }^{34}$

Even if the Sierra Club's charge-that the political activity proscriptions are vague-is rejected, considerable sympathy is merited for their charge that the requirements invite "unequal and spotty enforcement." ${ }^{35}$ It has been argued that cost and other administrative considerations render the IRS's review activities sporadic at best and that the choice of organizations for review is not likely to be random. ${ }^{36}$ Our own investigation of the pattern of activities by environmental CIGs leads us to hypothesize that the political activity restrictions are, if anything, underenforced in terms of the construction that might reasonably be placed on the language of the regulations. While a quantitatively generous scope of activity is thus implied, a certain qualitatively restrictive bias can be expected under these circumstances. In particular, the larger, more visible organizations and those who engage in programs which are controversial and highly publicized are more likely to invite adverse scrutiny. In probabilistic terms, the "cost" of certain political activities is inflated relative to less blatant ones. More even-handed, albeit more restrictive, enforcement is perhaps further compromised by the inability of interested citizens to challenge the tax deductibility of entities believed to be engaging in impermissible forms of political activity. ${ }^{37}$

For all of the furor it has aroused, the extent of the long term dampening effect of the Sierra Club revocation upon environmentalist CIGs is at least open to serious question. In any event, we speculate that the real behavioral implications for CIGs flow less from the question, "does this activity violate the Code?" than from the worry, "will this activity cause the Code to be invoked?"

Our third point argues that, given the existing production function for "environmental impact," the total impact of environmentalist CIGs on policy would probably have differed very little in the absence of the political proscriptions now present in the Code and its interpretative regulations. This point can be couched conceptually in terms of a standard economic maximization model. ${ }^{38}$

34. See Letter Ruling, supra note 32 , f 54,530-531.

35. Sierra Club's statement in Hearings on the Subject of Tax Reform Before the House Comm. on Ways and Means, 91 st Cong., lst Sess., ser. 15, pt. 2, at 913 (1969).

36. Note, The Revenue Code and a Charity's Politics, 73 YALE L.J. 661, 665 (1964).

37. The exclusive right of the IRS to initiate withdrawal of exempt status is discussed in $i d$. at 665-66 n.19, citing Massachusetts v. Mellon, 262 U.S. 447 (1923):

And how would a contributor challenge the "ruling" [of deductibility] except by refusing to deduct the contributions-an unnoticed act of defiance which would be to his financial detriment. The ordinary taxpayer who might disapprove of the Treasury's selection would have no standing to object in court because of an alleged improper narrowing of the tax base and the subsequent alleged harm to him.

38. The model used below will be recognized as an adaptation of the consumer choice mod- 
The CIG is assumed to wish to maximize a well defined ${ }^{39}$ preference $^{2}$ index which is a function of various types of "impacts" the CIG produces, e.g., public opinion, legal precedents, and regulatory or administrative decisions. ${ }^{40}$ The output produced of any particular impact will, in turn, be a function of (1) the instrumental activities carried on, such as mailings, lobbyists hired, press releases issued, etc.; and (2) certain relevant institutional and environmental aspects of the external world in which CIGs operate. ${ }^{41}$ The choice of activities also determines the CIG's resource constraint because the activities both absorb revenues via their money costs and, in addition, influence incoming revenue flows through their possible effect on public or foundation support, the entity's tax status, and so on. ${ }^{42}$

Maximization of the preference index, subject to impact and resource constraints, will yield optimal input values (some of which may be zero) for the various possible activities which a CIG may conduct. ${ }^{43}$ In the formal sense, our argument is that, even with liberalized political constraints, the solution set of optimal inputs and, implicitly, the impacts would not have altered appreciably. Ceteris paribus, activities should tend to be heavily utilized when they are "cost effective," i.e., when their "impact productivities" are high relative to their costs. ${ }^{44}$ Consequently, the response to change in the statutes will tend to be minimized when the induced effects of such external variables on the impact productivities and the revenue effect of "important" in put activities are

els. See, e.g., G. Becker, Economic Theory 45-50 (1971); Lancaster, Change and Innovation in the Technology of Consumption, 56 Am. Econ. Ass'N Proceedings 14 (1966).

39. For expositional simplicity, the group nature of a CIG's decision process is ignored. The potential difficulties inherent in the formulation of a group decision function were first pointed out in R. Arrow, Social Choice and Individual Values (2d ed. Cowles Foundation Monograph No. 1,1951 ).

40. The preference index $\mathrm{Z}$ is a function of $\mathrm{Z}$ 's which symbolize different possible impacts.

$\mathrm{Z}=\mathrm{Z}\left(\mathrm{z}_{1}, \mathrm{z}_{2}, \ldots, \mathrm{z}_{\mathrm{n}}\right)$

41. Produced levels of the $z$ 's are, in turn functions of $x$ 's which denote "input" activities of an exogenous variable and $E$.

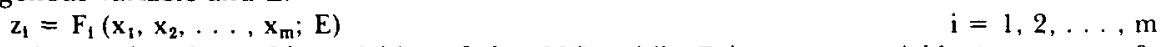

The $x$ 's are the observable activities of the CIGs while $E$ is a state variable (or vector of such variables) which describes relevant aspects of the external world in which CIGs operate. Legal precedents, public receptiveness, the status of tax laws, etc., are incorporated in the state variable E.

42. The resource constraint is a function of the CIG's own activities and of external conditions.

$\mathbf{R}=\mathbf{R}\left(\mathbf{x}_{1}, \mathbf{x}_{\mathbf{2}}, \ldots, \mathbf{x}_{\mathrm{m}} ; \mathrm{E}\right)$

43. See G. BECKER, supra note 38; Lancaster, supra note 38 .

$\mathbf{R}=\mathbf{R}_{\mathbf{0}}$

44. The $z_{1}$ constraint is collapsed into the preference index $Z$ and maximized. "Impact productivities" are the marginal products or incremental changes in any given "impact" $\mathrm{i}$ as a particular instrumental activity $\mathrm{j}$ is varied. This may be represented mathematically by $\frac{\partial z_{i}}{\partial \mathrm{x}_{\mathrm{j}}}$ for inputs and $\frac{\partial z_{i}}{\partial R}$ for resources. 
small. ${ }^{45}$ We speculate that this condition has been approximately satisfied by CIGs during recent years. The empirical evidence suggests to us that nonpermissible political activities, such as lobbying, have been of fairly low costeffectiveness relative to alternative permissible activities such as litigation and media publicity. In the following discussion, different classes of inputs, such as lobbying or litigation, may be understood as separate subsets of those activity inputs which produce "impacts" and reflect revenue resources.

Environmentalist lobbyists claim to have influenced a wide range of legislation. ${ }^{46}$ Doubtless, they did have perceptible effects on the drafting and enactment of environment-related legislation. The precise impact of the lobbyists is difficult to document or quantify, however. In many cases where the influence of the environmental lobbyists is alleged to have been strong, there have been other powerful political forces which had reasons to militate in favor of essentially the same legislative result. ${ }^{47}$ One hesitates, therefore, to attempt an imputation of particular results to particular lobbying efforts. Without denigrating in any way the lobbying efforts of the environmentalist CIGs, we prefer to point out what appears to be the greater cost-effectiveness of alternative activities such as the molding of public opinion and litigation.

Through effective use of media, environmentalist CIGs have probably been extremely instrumental in awakening public opinion to environmental issues during the late 1960s and early 1970s. ${ }^{48}$ The molding of public opinion is technically a "gray area" of political activity under the Code. On one hand, the IRS specifically appears to countenance such activity, recognizing that ${ }^{49}$

45. Denoted by $E$, the effect of a change in the statutes on $z_{i}$ and $R$ is given by

$$
\frac{\partial^{2} z_{i}}{\partial x_{\jmath} \partial E}
$$

Economists would term this the "cross-effect" of $E$ on the impact productivity of activity $Z_{1}$.

46. Conversations with environmental lobbyists elicited the following examples: Energy Supply and Environmental Coordination Act of 1974, 15 U.S.C.A. $\S \S 791,792$ (Supp. 1975); The Wild and Scenic Rivers Act, 16 U.S.C. \$ 1274 (Supp. I1I, 1974), amending 16 U.S.C. \$ 1274 (1970); Federal Aid to Highway Act of 1973, 23 U.S.C. $\$$ 101,104 (Supp. I1I, 1973), amending 23 U.S.C. $\$ \S 101,104$ (1970); Federal Water Pollution Control Act of 1972, 33 U.S.C. $\$ 1251$ (Supp. III, 1973), amending 33 U.S.C. \$ 1151 (1970); Clean Air Act, 42 U.S.C. \$ 1857 (1970); Safe Water Drinking Act, Pub. L. No. 93-523, 88 Stat. 1660 (1974), amending 42 U.S.C. $\$ 300$ (Supp. III, 1973); Big Cyprus National Preserve, Pub. L. No. 93-440 (1974), amending 16 U.S.C. \$ 698 (1970); Strip Mining Bill, H.R. 3383, S. 425, 93d Cong., 2d Sess. (1974). For other indications of environmentalists' lobbying activities, see lobbyists' registrations reported in the Congressional Quarterly Index and Almanac.

47. For instance, environmentalists successfully favored diversion of federal highway trust fund revenues to aid mass transportation. See Federal Aid to Highway Act of 1973, 23 U.S.C. $\$ \$$ 101.104 (Supp. 11I, 1973). But, quite apart from its environmental implications, the diversion was of crucial financial importance to the "urban" lobby.

48. An analysis of the generation of newspaper publicity by Los Angeles environmentalists is currently in preparation by George Papadatos, Ph.D. candidate in economics at the Center for Study of Public Choice, Virginia Polytechnic Institute and State University.

49. Treas. Reg. $\S 1.501(\mathrm{c})(3)-1(\mathrm{~d})(2)$ (1967). 
the fact that an organization, in carrying out its primary purpose, advocates social or civic changes or presents opinion on controversial issues with the intention of molding public opinion or creating public sentiment to an acceptance of its views does not preclude such organizations from qualifying under section $501(c)(3)$ so long as it is not an "action" organization.

On the other hand, the "action organization" test has provided a sufficiently ambiguous criterion to permit IRS challenges of deductibility on "propaganda" grounds in a number of cases, ${ }^{50}$ even where mere opinion-molding rather than overt lobbying is involved. De facto, the IRS has not seemed disposed to apply this test restrictively in the environmental area, possibly because the "opinion molding" is typically couched in discrete terms. ${ }^{51}$ Such discretion includes reference to conditions which require correction (but not to specific legislation) and heavy reliance on "educational" factual material designed to elucidate the CIG's viewpoint. Although the phraseology of CIG pamphlets observes certain conventions which reflect the political proscriptions, the effectiveness of the underlying message appears to have been little diminished. ${ }^{52}$

The environmentalist CIGs have even wider latitude with respect to statements about administrative or regulatory decisions or about litigation. While the direct or nominal purpose of such statements is nonlegislative, they frequently contribute to the public climate for future remedial legislation. Moreover, the generation of publicity is often an extremely low-cost proposition, open even to the small local CIG which relies on volunteer staff but effectively manages to dramatize local issues. In our view, this mobilization of public opinion, analogous to the private sector institutional advertising campaign, has ultimately been much more cost-effective than the types of direct legislative contact and political intervention which are restricted by the Code.

Notwithstanding the success of the CIGs in this "marketing" of environmental issues through the media to the public, and thence the legislature, a persuasive case can be made that the courts have actually been the principal instrument of policy impact. The CIGs are a large and growing force in environmental litigation, acting as principal plaintiffs in 24 per cent of the 1,145 major environmental cases reported in the period May 1970 to October 1974 and as principal plaintiffs in 45 per cent of the 181 cases during the last ten months of that period. ${ }^{53}$ One-third of the CIG cases were concentrated among three major national groups, the Environmental Defense Fund, the Natural Resources Defense Council, and the Sierra Club, of which only the

50. See the general discussion in Garrett, supra note 24 , at 578-8I and the cases cited therein.

51. It would be difficult to apply the adjective discrete to the materials used by the Sierra Club in the 1966 period preceding revocation,

52. E. Berlin, A. Roisman, \& G. Kessler, supra note 19, at 27.

53. This tabulation is based on the rases reported in I ERC (1970) through 6 ERC (1974). 
latter is not a $501(\mathrm{c})(3)$ entity. ${ }^{54}$ However, even modest-sized local CIGs have also been influential in a number of key cases. ${ }^{55}$ Such tabulations understate the litigation participation of CIGs in several respects since they fail accurately to account for CIGs included in the et al. faction, ${ }^{56}$ in special-purpose coalitions, ${ }^{57}$ in amicus curiae capacities, ${ }^{58}$ or as legal or supportive instrumentalities. ${ }^{59}$ However, the pervasive quantitative influence of CIGs in this aspect of environmental policymaking is clear, even from a conservative tabulation. In addition, a vast quantity of publicity is generated for environmental purposes by cases which are merely threatened, settled out of court, dropped, consolidated, etc.

Besides a quantitatively high level of participation, CIGs have achieved a qualitatively significant record in terms of the impact on environmental policy of judicial decisions handed down in CIG-initiated cases. For instance, the environmental groups have motivated key decisions in the law of standing ${ }^{60}$ and have succeeded in obtaining expansionary judicial interpretations of recent environmental legislation. Such interpretations are exemplified by the "non-degradation" clear air ruling ${ }^{61}$ and the series of cases $^{62}$ spelling out the requirements of environmental impact statements under the National En-

54. Id

55. Examples are numerous. One of the most far-reaching of the state environmental policy cases is Friends of Mammoth v. Board of Supervisors of Mono County, 8 Cal. 3d 247, 502 P.2d 1049, 104 Cal. Rptr. 761 (1972). The standing of citizens to bring suit on grounds of aesthetic and conservational injuries was established in Scenic Hudson Preservation Conference v. Federal Power Comm'n, 354 F.2d 608 (2d Cir. 1965).

56. E.g., Desert People United was a co-plaintiff in the major case City of Riverside v. Ruckelshaus, 4 ERC 1728 (C.D. Cal. 1972).

57. A case in point is Clean Air Constituency v. California State Air Resources Bd., 11 Cal. 3d 801,523 P.2d 617, 114 Cal. Rptr. 577 (1974) in which the plaintiff represented a coalition of ten environmental groups including the Sierra Club and the League of Women Voters.

58. In the case of County of Inyo v. Yorty, 32 Cal. App. 3d 795, 108 Cal. Rptr. 377 (Ct. App. 1973), amicus curiae briefs were filed by the Izaak Walton League, Center for Law in the Public Interest, Case Docket, December 1972, at 31, and by Sierra Club Legal Defense Fund, Inc., 5 ERC 1431 (1973).

59. The plaintiffs in City of Riverside v. Ruckelshaus, 4 ERC 1728 (C.D. Cal. 1972), were represented by the Center for Law in the Public Interest, a 501(c)(3) law group.

60. Environmental Defense Fund v. Hardin, 428 F.2d 1093 (D.C. Cir. 1970); Scenic Hudson Preservation Conference v. Federal Power Comm'n, 354 F.2d 608 (2d Cir. 1965); Road Review League v. Boyd, 270 F. Supp. 650 (S.D.N.Y. 1967). See generally Note, Citizen Organizations Intervening in Federal Administrative Proceedings: The Lingering Issue of Standing, 51 Boston U.L. REV. 403 (1971); Note, Standing: Who Speaks for the Environment?, 32 MoNT. L. REv. 130 (1971) and cases cited therein.

61. Sierra Club v. Ruckelshaus, 344 F. Supp. 253 (D.D.C. 1972), aff'd per curiam, 4 ERC 1815 (D.C. Cir. 1972), aff'd by an equally divided court sub nom. Fri v. Sierra Club, 412 U.S. 54 (1973). The case centered on whether the phrase "enhance and protect" of $\S 101(\mathrm{~b})(1)$ of the Clean Air Act of 1970,42 U.S.C. $\$ 1857$ (1970) should be interpreted to required state implementation plans to prohibit significant deterioration of clean air areas.

62. See generally Jordan, Alternatives Under NEPA: Toward an Accomodation, 3 EcoLoGy L.Q. 705 (1973) and the numerous cases cited therein. See also. F. ANDerson \& R. Daniels, NEPA in THE Courts 179-245 (1973). 
vironmental Policy Act (NEPA). ${ }^{63}$ It is said to be "universally accepted that the courts have shaped NEPA, and the federal process under it, in a manner unprecedented in the history of federal programs." 64 We argue below that much of the CIG litigation was actually quasi-legislative in its results, going beyond either congressional intent or expectation. Other litigation had its impact merely by insuring the rigorous application of provisions clearly spelled out in the statutes. ${ }^{65}$ From whatever standpoint, however, it is difficult to escape the conclusion that litigation was far and away the most efficacious activity carried on by environmentalist CIGs during the past decade.

If our assessment of the relative efficacy of CIG activities is correct, the influence of the CIGs was virtually unimpaired by any limitations inherent in the definition of a $501(\mathrm{c})(3)$ organization because the most highly costeffective activities are not seriously circumscribed by regulation. Hence, as presently enforced by the IRS, the attempted regulation of political activity may be regarded as a nuisance, but not as economically meaningful a constraint as it nominally appears. This view does not necessarily extrapolate without qualification into the future. At least with respect to those key decisions that establish widely applicable precedents, it may be argued that the very success of the CIGs has narrowed the possibilities for achieving new breakthroughs within the framework of the existing statutes. On the other hand, the role of the CIGs as "private attorneys general" is wide open for continued development.

\section{III}

\section{The Political Economy of the Current Law}

In this final section, our focus shifts slightly from "ordinary" economics to political economy, from what is to what perhaps ought to be. Attention is given to two principal problem areas: (1) the legal distinction between "legislative" and other political activity; and (2) compatibility between controversiality and subventions for private providers of "public goods."

63. National Environmental Policy Act, 42 U.S.C. \$ 4322(c) (1970) requires the preparation of environment impact statements for "proposals for legislation and other major Federal actions significantly affecting the quality of the human environment." Early cases centering on the meaning of "major" and "significantly" in which CIGs were plaintiffs include Monroe County Conservation Council v. Volpe, 472 F.2d 693 (2d Cir. 1972); Citizens Organized to Defend the Environment v. Volpe, 353 F. Supp. 520 (S.D. Ohio 1972); Natural Resources Defense Council v. Grant, 341 F. Supp. 356 (E.D.N.C. 1972).

64. H. Yarrington, The National Environmental Policy act (BNa Environmental Report Monograph No. 17, 1973).

65. Riverside v. Ruckelshaus, 4 ERC 1728 (C.D. Cal. 1972) found that EPA's failure to promulgate, within sixty days, proposed transportation controls to replace a disapproved state plan was in violation of a nondiscretionary duty imposed by section 110 of the Clean Air Act of 1970 , 42 U.S.C. $\S 1857 \mathrm{c}-5$ (c) $(1970)$. 
Economists are trained to think in terms of the "equilibrium" of a model, the set of results which emerge. Hence, they tend to equate policies which produce identical results. For instance, they recognize that regardless of alterations in the assignments of the legal liability for certain taxes, the location of the economic burden or "incidence" is frequently invariant. ${ }^{66}$ In the context of public policy analysis, political activities which produce substantially equivalent results would be regarded as themselves equivalent. For this reason, the particular focus of the political constraints as being principally on legislative and elective politics takes on the character of a distinction without a difference. Indeed, the attempted distinction is belied by the enormous quasilegislative policy impacts that CIGs have secured through the courts and through various forms of administrative pressure.

With respect to litigation carried on by the environmentalists, we would distinguish between two conceptually separable functions. One is to enforce a right which is well established by virtue either of clear statutory language or prior judicial precedent. "Enforcement" is illustrated in Riverside $v$. Ruckelshaus ${ }^{67}$ and Wilderness Society $\%$. Morton ${ }^{68}$ where the courts held that federal administrators had violated clear statutory language. By contrast, "quasilegislative" action is involved where the CIGs have brought litigation which had the effect of filling interstitial gaps in the statutes.

Although there are numerous other examples, prominently including the nondegradation interpretation of the Clean Air Act, ${ }^{69}$ the judicial interpretation of the National Environmental Policy Act is perhaps the best single illustration of successful quasi-legislative effort by the environmentalist CIGs. ${ }^{70}$ The ultimate impact of NEPA is especially interesting because of the evidence that most members of Congress were unaware of the implications of what they were passing, ignoring as they did any debate on the sweeping Title I action-forcing clauses which have been the keystone of recent environmental

66. This is important, for example, in assessing the burdens from the nominal "employer contribution" to FICA payments. See note 5 supra. An analogous example from international economics is discussed in Shibata, $A$ Note on the Equivalence of Tariffs and Quotas, 58 AM. Econ. REV. 137 (1968).

67. 4 ERC 1728 (C.D. Cal. 1972).

68. 479 F.2d 842 (D.C. Cir. 1973). This judgment held that the rights-of-way issued by the Secretary of the Interior for the Trans-Alaskan Pipeline System (TAPS) exceeded the power granted to him under section 28 of the Mineral Leasing Act of 1920, 30 U.S.C. $\$ 185$ (1970).

69. See note 61 supra. A general history of litigation under the Clean Air Act can be found in C. Bolbach, The Courts and the Clean Air Act (BNA Environmental Report Monograph No. 19, 1974)

70. See note 62 supra. On NEPA generally, see also Crampton \& Berg, On Leading a Horse to Water: NEPA and the Federal Bureaucracy, 71 Mich. L. Rev. 511 (1973); Peterson, An Analysis of Title I of the National Enirironmental Policy Act of 1969, 1 Environmental L. ReP. 50035 (1970); Note, The National Environmental Policy Act: A Sheep in Wolf's Clothing, 37 BrookLyn L. Rev. 139 (1970); Note, Evolving Judicial Standards Under the National Environmental Policy Act and the Challenge of the Alaska Pipeline, 81 YALE L.J. 1592 (1972). 
litigation. ${ }^{71}$ Consequently, it is debatable whether there even existed a true legislative intent to be interpreted in this case.

As viewed by a social scientist, there is very little difference between case law and statutory law, since their ability to shape results is virtually indistinguishable. It may correctly be objected that interpretive case law, when it violates legislative intent, can be overturned by statutory clarification. But it is not difficult to make a case, based on such factors as the transactional cost of political coalition formation, that the status quo occupies a strongly favored position in any collective decision-making process. Due to inertial considerations, laws which are incapable of legislative passage may, once effectuated, be incapable of repeal. Hence, we argue that it would be appropriate to view the process of affecting judge-made law under the same regulatory principles adopted for statutory law.

A similar chain of logic suggests that the distinction between legislative and administrative activity is also ill-founded. Indeed, the actions of administrators are themselves frequently quasi-judicial (as when statutory provisions are interpreted) or quasi-legislative (as when EPA issues "standards" under its Clean Air Act powers). Logically, this line of argument would conclude that attempts to influence administrative policy formation frequently do not differ operationally from attempts to alter legislative policy. The instruments by which environmentalist CIGs accomplish such influence include presently permissible activities such as media criticism (which may be highly personal) and threats to litigate.

In rejecting the legal distinction currently attempted under the tax code with respect to elective and legislative politics, we do not necessarily prejudge whether consistency should be effected through extension of the prohibition to all forms of political activity or through the converse policy of liberalization. However, we do find some economic considerations, as opposed to legal ones, which raise questions about public subvention of any controversial activity.

The legal literature attaches considerable importance to the interpretation of the statutory term "charitable." 72 By approaching the tax treatment question strictly from the standpoint of modern welfare economics and public $\mathrm{f}_{1}$ nance, a rationale for public subvention can be elaborated which is conceptually independent of the ambiguous notion of charity. Fundamental to this approach is a concept of an activity which produces positive "externalities" or

71. See Note, The National Environmental Policy Act of 1969 and the Energy Crisis: The Road to Alaska, 10 Colum. J. L.aw \& Social Prob. 265, 268 \& nn.11-16 (1974).

72. Clark, supra note 24, at 440; Hobbet, Public Interest Law Firms-To Fee or Not to Fee, 27 Nat'l TAX J. 45, 46 (1974); Note, The Tax-Exempt Status of Public Interest Law Firms, 45 S. CAL. L. REv. 228, 232 (1972). 
"spillovers" to persons other than the one carrying on the activity. ${ }^{73}$ When private activity provides both a direct private good and also an indirect spillover benefit to others, the collectivity may have an economic interest in stimulating the provision of this "quasi-public" good. The clearest case of this arises when the privately provided good supplants an activity which might otherwise have been provided at government expense. The 501(c)(3) language reflects this rationale by explicitly listing "erection or maintenance of public buildings, monuments, or works" and "lessening of the burdens of Government." ${ }^{74}$ The governmental burden-reduction element is a sufficient but not a necessary condition for subvention. It is overly restrictive to require that the government would have carried on a similar activity itself, since direct government provision, as opposed to the subvention of a private producer, may be much less cost-effective. In any event, the rationale of subsidization, including subsidization through tax deductibility, boils down to an economically superior way, in certain cases, of providing "something that the collectivity wants" or "something in the public interest," the latter not necessarily being construed altruistically.

This conception is perfectly compatible with many activities traditionally regarded as charitable. The governmental burden-reduction argument has explicitly been adduced with respect to the extremely important litigation activities of CIGs. For example, the IRS suspension of rulings on claims for tax exempt status by public interest law firms in the fall of 1970 evoked a number of responses. Russell Train, Chairman of the Council on Environmental Quality, argued in favor of tax-exempt status for public interest law firms on the basis of (1) the government's recognition of the importance of private litigation in the enforcement of environmental regulations and (2) the court's recognition of the right of private plaintiffs to sue to protect the public interest. ${ }^{75}$ However, we would distinguish, as discussed above, between enforcement and quasi-legislative litigation. The former fairly clearly supplements governmental efforts in the implementation of existing law. Even when such enforcement is "controversial," it can at least be argued that it is legitimatized by a previous majority-rule collective decision so long as the enforcement falls within the clear intent of the enabling legislation. Hence, private enforcement, as we narrowly define it, enjoys a strong prima facie presumption that it provides a majority-approved collective good. By contrast, the status of quasi-legislative activity, whether through litigation or otherwise, does not seem to warrant such a presumption.

73. For an expansion of some of the economic notions used in this section, see Davies, Financing Urban Functions and Services, 30 LAw \& Contemp. Prob. 127, 132 (1965).

74. Treas. Reg. § $1.501(\mathrm{c})(3)-1(\mathrm{~d})(2)(1967)$.

75. Letter and memorandum from Russell Train, Chairman, Council on Environmental Quality to Randolf Thrower, IRS Commissioner, Sept. 30, 1970, in I BNA ENvironmental ReP. 745 (1970). See also note 25 supra. 
An unemotional characterization of quasi-legislative activity is, after all, that it is simply an attempt to establish a rule without going through the normal channels of political process. Subjective goodness of intent and the existence of benefits to a set of third parties should not be sufficient when the impact of the proposed rule is controversial. Such controversiality ipso facto implies that an additional, and substantial, set of third parties is injured, or at least does not find the activity in question to be meritorious of public subvention. With respect to some private activities, such as education and relief of the poor, society has apparently reached at least a tacit consensus that subvention is warranted, that the net benefits of subsidization are beneficial to a majority. It may well be that the net benefits even of "controversial" environmentalist activity are or will be recognizable as positive by a majority political coalition, but it is precipitate to accept this presumption uncritically without specific evidence and debate.

There is, after all, evidence that the members of some of the most influential environmentalist CIGs are not at all a representative cross-section of the population. Numerous studies of the Sierra Club, for instance, find that its members rank significantly higher than the general population in income, education, and occupational status. ${ }^{76}$ However, it may be regarded as invalid to generalize from the membership of the Sierra Club to the membership of the estimated 20,000 other environmentalist CIGs in the United States, many of whom are quite small and concerned with other aspects of environmental quality such as air and water pollution, land use, nuclear hazards, and waste disposal. ${ }^{77}$ Using data from a nationwide survey of environmentalist CIG members conducted by the National Center for Voluntary Action, ${ }^{78}$ Dunlap has been able to produce socioeconomic comparisons with general population census data for EPA Regions III and VIII. ${ }^{79}$ These are summarized in Table I. While considerable, the income disparity between active members of environmentalist CIGs and the general public appears smaller than the differences in education and occupational status. The more limited sample of sur-

76. Coombs, The Club Looks at Itself, 57 Sierra Club Bull. 35 (Jul./Aug. 1972); Devall, Conserzation: An Upper Middle Class Social Movement: A Replication, 2 J. Leisure Research 123 (1970); Faich \& Gale, The Environmental Movement: From Recreation to Politics, 14 PAcific Sociological. Rev. 270 (1971); Harry, Gail, \& Hendee, Conservation: An Upper Middle-Class Social Movement, 1 J. LeISURE RESEARCh 129 (1969).

77. R. DunlaP, supra note 11 , at 4 .

78. The survey itself is described in Smith, Methodology of the Study "Profile of the Environmental Motiement," in National Technical Information Service, Exvironmental Volunteers in AMERICA (1972).

79. R. Dunlap, supta note 11, at 13. EPA Region III consists of Pennsylvania, Virginia, West Virginia, Maryland, and Delaware, plus the District of Columbia. Region VIII includes Colorado, Utah, North Dakota, South Dakota, Wyoming, and Montana. The five metropolitan areas are St. Louis; San Francisco; Birmingham; Durango, Colorado; and Amherst, Massachusetts. 
vey respondents from other EPA Regions is even higher in socioeconomic status. ${ }^{80}$

TABLE I

Sociofconomic Characteristics of Environmentalists Compared

With General Population, ${ }^{a}$ By EPA Region

\begin{tabular}{|c|c|c|c|c|}
\hline \multirow[b]{2}{*}{ Characteristics } & \multicolumn{2}{|c|}{ Region III } & \multicolumn{2}{|c|}{ Region VIII } \\
\hline & Environment & Population & Environment & Population \\
\hline \multicolumn{5}{|l|}{ Education: ${ }^{\mathrm{b}}$} \\
\hline $\begin{array}{l}\text { Some high school } \\
\text { High school graduate } \\
\text { Some college } \\
\text { College degree } \\
\text { Graduate work }\end{array}$ & $\begin{array}{l}5.8 \% \\
14.7 \\
18.5 \\
21.5 \\
39.6\end{array}$ & $\begin{array}{l}50.2 \% \\
30.9 \\
8.3 \\
5.9 \\
4.6\end{array}$ & $\begin{array}{l}3.6 \% \\
9.7 \\
21.4 \\
24.6 \\
40.8\end{array}$ & $\begin{array}{l}39.0 \% \\
33.6 \\
14.9 \\
7.3 \\
5.3\end{array}$ \\
\hline \# of cases & $(655)$ & $(12,898,451)$ & $(248)$ & $(2,841,468)$ \\
\hline $\begin{array}{l}\text { Occupation:c } \\
\text { Professional/Techni- } \\
\quad \text { cal/Academic } \\
\text { Mgr./Administrator } \\
\text { Sales } \\
\text { Clerical/Office } \\
\text { Service } \\
\text { Agriculture } \\
\text { Skilled labor } \\
\text { Unskilled labor }\end{array}$ & $\begin{array}{l}55.8 \% \\
15.3 \\
3.0 \\
6.4 \\
1.8 \\
3.2 \\
9.6 \\
4.8\end{array}$ & $\begin{array}{c}15.3 \% \\
7.6 \\
6.7 \\
18.3 \\
12.3 \\
1.7 \\
14.4 \\
23.6\end{array}$ & $\begin{array}{c}60.7 \% \\
12.4 \\
4.1 \\
2.1 \\
1.4 \\
15.2 \\
3.4 \\
.7\end{array}$ & $\begin{array}{c}16.1 \% \\
9.6 \\
7.0 \\
16.6 \\
14.1 \\
8.8 \\
12.4 \\
15.4\end{array}$ \\
\hline \# of cases & $(437)$ & $(8,885,431)$ & $(145)$ & $(2,017,017)$ \\
\hline $\begin{array}{l}\text { Family Income: } \\
\text { Under } \$ 4,999 \\
5,000-9,999 \\
10,000-14,999 \\
15,000-24,999 \\
25,000 \text { and over }\end{array}$ & $\begin{array}{l}3.8 \% \\
18.5 \\
27.9 \\
33.4 \\
16.4\end{array}$ & $\begin{array}{l}18.7 \% \\
34.8 \\
26.6 \\
15.4 \\
4.5\end{array}$ & $\begin{array}{l}7.0 \% \\
20.7 \\
27.8 \\
32.6 \\
11.9\end{array}$ & $\begin{array}{l}21.5 \% \\
36.5 \\
25.5 \\
12.9 \\
3.6\end{array}$ \\
\hline \# of cases & $(736)$ & $(5,902,418)$ & $(270)$ & $(1,363,597)$ \\
\hline
\end{tabular}

Source: R. Dunlap. The Socioeconomic Basis for the Environmental Movement: Old Data. New Data, aNd IMPlications for the MOVement's Fltere (Washington State University Scientific Paper No. 4350, 1974).

apopulation data for each region obtained by combining appropriate census data on all states in that region. All data obtained from 1 U.S. Bureau of the Census, Dep't of Commerce, 1970 Census of Population: Characteristics of the Population ch. c, Tables 46, 54, 57, for all fifty states (1973).

${ }^{b}$ Educational data reported on those iwenty-five years and older.

'Occupational data reported on those sixteen years and over.

80. Id. 
Socioeconomic atypicality is not, of course, necessarily linked with atypicality in regard to policy issues. With respect to environmental issues, however, casual empiricism suggests that the willingness to purchase higher environmental quality at the cost of higher prices, job losses, etc. may be positively linked with high income and status. Dunlap, a sociologist who has specialized in the study of the environmental movement, ${ }^{81}$ seems to share the judgment of the authors that the atypical socioeconomic character of the environmentalist CIGs portends problems for the future as the "honeymoon" over the environment fades and the conflicts with other "public" interests, such as those of industrial workers and the urban poor, come into increasingly sharper focus. ${ }^{82}$ If the environmental groups do indeed emerge as substantially unrepresentative in the views they advocate, this does not carry the additional implication that they are more unrepresentative than many other activist groups organized around other issues. However, such conflict considerations do underscore the difficulties in properly construing the term "charitable" for purposes of public subvention.

We may summarize by saying that the potential economic basis of a subvention to private activity is extremely wide. The notion of a publicly subsidized but privately provided collective good is not limited to "charitable" activities nor does it necessarily exclude "political" or controversial activities. Nevertheless, a controversial activity should arguably be required to meet some test of a political consensus to ensure that it qualifies as a collective good rather than a, however well-intentioned, collective bad. The continued ability of the de facto political activities of the environmentalist CIGs to meet such a test is at least questionable.

\footnotetext{
81. In addition to the works cited supra note 11 , see R. Dunlap, The Impact of Political Orientation on Environmental Attitudes and Actions (Washington State University Department of Sociology working paper 1974); Dunlap, Gale, \& Rutherford, Concern for Environmental Rights Among College Students, 32 Am. J. Econ. \& Sociology 45 (1973); Dunlap \& Gale, Party Membership and Environmental Politics: A Legislative Roll-Call Analysis, 55 Social Science Q. 670 (1974); Dunlap \& Gale, Politics and Ecology: A Political Profile of Student Eco-activists, 3 YouTH AND SOCIFTy 379 (1972).

82. R. DUNLAP, supra note 11 , at $18-25$.
} 